\title{
MIGRASI RISEN DI PROVINSI NUSA TENGGARA BARAT BERDASARKAN HASIL SP 2010 DAN SUPAS 2015
}

\author{
LALU MUH. KABUL \\ Universitas Teknologi Mataram \\ e-mail: kabullpp@yahoo.com
}

\begin{abstract}
ABSTRAK
Penelitian ini berbeda dengan penelitian sebelumnya dimana fokus penelitian ini adalah migrasi risen antar kabupaten/kota di satu provinsi yakni Nusa Tenggara Barat. Tujuan penelitian ini adalah menganalisis pola migrasi risen masuk, migrasi risen keluar dan migrasi risen neto. Dalam penelitian ini digunakan metode deskriptif kuantitatif. Hasil penelitian ini menunjukkan bahwa terjadi peningkatan migrasi risen masuk, migrasi risen keluar dan migrasi neto antara tahun 2010 dan 2015. Pola migrasi risen masuk dan migrasi risen keluar antara tahun 2010 dan 2015 adalah sama yakni terjadi peningkatan pada 7 kabupaten/kota dan penurunan pada 3 kabupaten/kota. Pola migrasi risen neto antara tahun 2010 dan 2015 adalah berbeda dimana pada tahun 2010 migrasi risen neto negatif terjadi pada 6 kabupaten/kota, migrasi risen 0 (nol) pada 1 kabupaten dan migrasi risen neto positif pada 3 kabupaten. Sementara pada tahun 2015 terjadi migrasi risen negatif terjadi pada 5 kabupaten/kota dan migrasi risen positif pada 5 kabupaten/kota. Perubahan dari migrasi risen neto negatif pada tahun 2010 menjadi migrasi risen neto positif pada tahun 2015 hanya terjadi pada 2 kabupaten.
\end{abstract}

Kata kunci: Migrasi risen masuk, migrasi risen keluar, migrasi risen neto

\begin{abstract}
The study is difference with previous studies where the study focused on recent migration among regency/municipality in one province namely West Nusa Tenggara. The aim of the study is to analysis pattern of in recent migration, out recent migration, and net recent migration. The study method used is descriptive quantitative. The result of study showed that in recent migration, out recent migration, and net recent migration increased between 2010 and 2015. The pattern of in recent migration and out recent migration between 2010 and 2015 was same increased in 7 regencies/municipalities and decreased in 3 regencies/municipalities. The pattern of net recent migration between 2010 and 2015 was difference negative net recent migration in 6 regencies/municipalities, zero net recent migration in 1 regency, and positive net recent migration in 3 regencies. Meanwhile, in 2015 it was negative net recent migration in 5 regencies/municipalities, and positive net recent migration in 5 regencies/municipalities. The change of negative net recent migration in 2010 toward positive net recent migration in 2015 it was occurred only in 2 regencies.
\end{abstract}

Keywords: In recent migration, out recent migration, net recent migration

\section{PENDAHULUAN}

Mobilitas penduduk dibedakan menjadi mobilitas penduduk vertikal dan mobilitas penduduk horizontal (Mantra, 2000). Mobilitas penduduk vertikal disebut juga perubahan status, contohnya perubahan status pekerjaan seseorang dari sektor pertanian sekarang bekerja di sektor non pertanian. Mobilitas penduduk horizontal disebut juga mobilitas penduduk geografis. Mobilitas penduduk horizontal dibedakan menjadi perpindahan penduduk dalam wilayah administratif yakni antar desa, antar kabupaten/kota, dan antar provinsi di suatu negara atau disebut migrasi internal dan perpindahan penduduk yang melintasi batas negara dari suatu negara ke negara lainnya sehingga terjadi perubahan negara yang menjadi tempat tinggal atau disebut migrasi internasional (Retno et al, 2008 ; UNDP, 2009). Di dunia, sekitar 740 juta penduduk 
melakukan migrasi internal atau hampir empat kali lebih banyak dibandingkan migrasi internasional. Disisi lain, sekitar 200 juta penduduk dunia yang melakukan migrasi internasional melakukan perpindahan dari suatu negara berkembang ke negera berkembang lainnya atau antar negara maju. Hanya sekitar sepertiga atau kurang dari 70 juta penduduk dunia yang melakukan perpindahan dari negara berkembang ke negara maju (UNDP, 2009).

Migrasi internal meliputi mobilitas penduduk permanen dan mobilitas penduduk non-permanen. Dalam pada itu, mobilitas yang dilakukan diniatkan untuk menetap di daerah tujuan selama paling sedikit enam bulan atau lebih maka digolongkan sebagai mobilitas permanen, jika diniatkan untuk tidak menetap digolongkan sebagai mobilitas non permanen. Disisi lain, mobilitas non-permanen meliputi ulang alik disebut juga "nglaju" (commuting) dan menginap/mondok (circulation) di daerah tujuan disebut juga migrasi sirkuler. Nglaju adalah gerak perpindahan penduduk dari daerah asal menuju daerah tujuan dan kembali ke daerah asal pada hari itu juga. Mobilitas sirkuler yakni gerak perpindahan penduduk meninggalkan daerah asal menuju menuju daerah tujuan selama lebih dari satu hari tetapi kurang dari enam bulan.

Penelitian mengenai mobilitas non-permanen tersebut antara lain telah dilakukan oleh Mantra (1978) di Daerah Istimewa Yogyakarta dan diperoleh hasil penelitian bahwa jumlah penduduk yang melakukan nglaju lebih banyak dibandingkan menginap/mondok dimana dalam mobilitas non permanen tersebut terdapat seperangkat gaya yaitu gaya sentrifugal dan sentripetal. Gaya sentrifugal merupakan faktor pendorong bagi penduduk untuk ke luar dari daerah asal berupa sempitnya pemilikan lahan, kurangnya peluang kerja di daerah asal. Sedangkan gaya sentripetal merupakan faktor penarik bagi mereka untuk kembali ke daerah asal yakni karena daerah asal merupakan tempat kelahiran, kepemilikan lahan, kuatnya kegotong-royongan. Penelitian mobilitas non-permanen lainnya, dilakukan oleh Bandiyono (2014) pada tahun 2004 dan 2005 di Kota Surabaya Provinsi Jawa Timur dan hasil penelitian tersebut adalah keberadaan migran non-permanen di Kota Surabaya sebagian besar berasal dari daerah perdesaan di Jawa Timur dan umumnya mereka bekerja di sektor informal dimana mereka umumnya tinggal di permukiman kumuh dan jumlahnya cenderung meningkat dan sebagian mereka masih membawa nilai-nilai dan cara hidup perdesaan (rural way of life) dan diantara mereka bahkan tinggal sebagai penghuni liar (squatters).

Mobilitas permanen mencakup migrasi seumur hidup (lifetime migration) dan migrasi risen (recent migration). Migrasi seumur hidup (life time migration) didefinisikan sebagai perpindahan penduduk melewati suatu wilayah administrasi dimana tempat tinggalnya saat ia dilahirkan berbeda dengan wilayah administrasi tempat tinggalnya saat pencacahan. Disebut migrasi risen jika tempat tinggalnya lima tahun yang lalu berbeda dengan tempat tinggalnya sekarang pada saat pencacahan. Penelitian tentang migrasi risen di Indonesia antara lain telah dilakukan oleh Mantra (1992), Bandiyono (2014), dan Sukamdi \& Gazy Mujahid (2015). Berdasarkan hasil penelitian Mantra (1992) diperoleh bahwa migrasi risen pada periode 1985-1990 ke provinsi-provinsi di Kawasan Timur Indonesia yakni Kalimantan, Maluku, dan Irian Jaya mengalami kenaikan yang berarti dibandingkan migrasi risen pada periode 1980-1985. Migrasi risen di Jawa dan Bali umumnya menuju perkotaan, sedangkan di luar Jawa dan Bali menuju perdesaan. Dalam pada itu, hasil penelitian Bandiyono (2018) menunjukkan bahwa pada tahun 1990 terjadi peningkatan migran masuk ke Kawasan Timur Indonesia (KTI) sebesar 51 persen dari provinsi-provinsi di Kawasan Barat Indonesia (KBI) dan sebaliknya migran keluar dari KTI ke KBI hanya 36 persen. Adapun pada tahun 1995 arus migran masuk ke KTI turun menjadi 49 persen dan sebaliknya arus migrasi keluar KTI menuju KBI meningkat menjadi 47 persen. Meskipun ada peningkatan arus migrasi keluar dari KTI menuju KBI namun arus migrasi masuk ke KTI masih lebih besar.

Disisi lain, dari hasil penelitian Sukamdi \& Gazy Mujahid (2015) diperoleh bahwa migrasi risen antar provinsi pada periode 2000-2010 mengalami penurunan sebesar 3,8 persen. Dari sisi pola migrasi dimana pola migrasi pada periode 1995-2000 dan 2005-2010 tidak banyak berubah. Migrasi masuk menuju pulaupulau di luar pulau Jawa sebagian besar berasal dari pulau Jawa dimana persentasenya meningkat untuk semua pulau kecuali Maluku dan Irian Jaya. Proporsi tertinggi migrasi masuk ke pulau Jawa baik pada 19952000 maupun 2005-2010 berasal dari pulau Sumatera, sementara persentase migrasi masuk ke Pulau Jawa dari pulau-pulau lainnya kecuali Sulawesi meningkat. Disisi lain Sunarto (1993) menyatakan bahwa secara historis migrasi telah dimulai pada masa kolonial Belanda yakni pada tahun 1905 dalam bentuk program transmigrasi dimana pemerintah kolonial Belanda pada waktu itu memindahkan penduduk Kedu Jawa Tengah menuju Gedong Tataan di Provinsi Lampung yang dikenal dengan kolonisasi.

Penelitian migrasi risen di tingkat provinsi antara lain dilakukan oleh Sudibia IK et al (2012) di Provinsi Bali dan diperoleh hasil penelitian bahwa jumlah migrasi risen yang masuk ke Provinsi Bali pada tahun 2010 cenderung meningkat dibandingkan pada tahun 2000. Sebaliknya jumlah migrasi risen yang ke luar dari Provinsi Bali cenderung menurun. Pola mograsi risen yang masuk ke Provinsi Bali pada tahun 2010 tidak berbedanya nyata dengan keadaan pada tahun 2000. Proporsi migrasi risen yang masuk ke Provinsi Bali didominasi oleh migrasi risen dari Provinsi Jawa Timur kemudian disusul oleh migrasi risen dari 
provinsi-provinsi lainnya di Pulau Jawa dan migrasi risen dari Provinsi Nusa Tenggara Barat dan Nusa Tenggara Timur. Pola migrasi rsien yang keluar dari Provinsi Bali pada tahun 2010 juga menunjukkan pola yang sama dengan keadaan tahun 2000. Daerah tujuan yang paling menonjol dari migrasi risen keluar dari Provinsi Bali adalah Provinsi Jawa Timur daerah tujuan lainnya adalah provinsi-provinsi di pulau Jawa dan disusul oleh migrasi risen yang menuju Provinsi Nusa Tenggara Barat dan Nusa Tenggara Timur.

Berdasarkan data BPS (2019) bahwa di Indonesia pada tahun 2018 terdapat tujuh provinsi yang memiliki persentase migrasi risen tertinggi yaitu Provinsi Kepulauan Riau (5,8 persen), Papua Barat (5,1 persen), Nusa Tenggara Barat (4,7 persen), Sulawesi Barat (4,7 persen), DKI Jakarata (4,5 persen), DI Yogyakarta (4,5 persen) dan Bali (4,5 persen). Meskipun Nusa Tenggara Barat tergolong sebagai salah satu provinsi dari tujuh provinsi dengan persentase migrasi risen tertinggi tetapi penelitian tentang migrasi di Provinsi Nusa Tenggara Barat lebih banyak difokuskan pada migrasi internasional (Haris, 2002; Novianti, 2010; Mantra, 1998; Wirasapta Karyadi, 2013) dan bukan pada migrasi risen. Oleh karena itu, penelitian migrasi risen berdasarkan hasil Sensus Penduduk (SP) 2010 dan hasil Survei Penduduk Antar Sensus (SUPAS) 2015 ini dilaksanakan di Provinsi Nusa Tenggara Barat (NTB). Sejumlah penelitian sebelumnya mengenai migrasi risen yang telah dilakukan oleh Mantra (1992), Bandiyono (2014), Sukamdi \& Gazy Mujahid (2015), dan Sudibia IK et al (2012) dimana penelitian difokuskan pada migrasi risen antar provinsi, bukan pada migrasi risen antar kabupaten/kota di suatu provinsi. Sedangkan penelitian ini berbeda dengan penelitian-penelitian sebelummya dimana penelitian ini difokuskan pada migrasi risen antar kabupaten/kota di satu provinsi yakni Provinsi NTB.

\section{Rumusan Masalah}

Rumusan permasalahan dalam penelitian ini adalah sebagai berikut: (1) bagaimana pola migrasi risen masuk antar kabupaten/kota di Provinsi NTB dalam pada tahun 2010 dan 2015 , (2) bagaimana pola migrasi risen keluar antar kabupaten/kota di Provinsi NTB pada tahun 2010 dan 2015, (3) bagaimana pola migrasi risen neto antara kabupaten/kota di Provinsi NTB pada tahun 2010 dan 2015.

\section{Tujuan}

Penelitian ini dilaksanakan dengan tujuan sebagai berikut: (1) menganalisis pola migrasi risen masuk antara kabupaten/kota di Provinsi NTB dalam periode 2010-2015, (2) menganalisis pola migrasi risen keluar antar kabupaten/kota di Provinsi NTB dalam periode 2010-2015, (3) menganalisis pola migrasi risen neto antar kabupaten/kota di Provinsi NTB pada tahun 2010 dan 2015.

\section{METODE PENELITIAN}

\section{Pendekatan}

Dalam penelitian ini digunakan pendekatan deskriptif kuantitatif (Neuman, 2014) yakni mendeskripsikan fenomena migrasi risen di Provinsi NTB secara kuantitatif pada tahun 2010 berdasarkan hasil SP 2010 dan tahun 2015 berdasarkan hasil SUPAS 2015. Migrasi risen yang dimaksud dalam penelitian ini adalah jika kabupaten/kota tempat tinggal seseorang lima tahun yang lalu berbeda dari tempat tinggal sekarang. Berkaitan dengan konsep tempat tinggal digunakan pendekatan de jure dan de facto dimana dalam pendekatan de jure yakni konsep tempat dimana biasanya seseorang menetap/tinggal, sedangkan dalam pendekatan de facto yakni tempat dimana seseorang berada pada waktu pencacahan.

Batas waktu migrasi ditetapkan 6 bulan sejalan dengan konsep tempat tinggal, artinya seseorang dikatakan migran jika tinggal di tempat baru atau berniat tinggal di tempat baru paling sedikit 6 bulan lamanya. Dalam pada itu, keterangan bahwa seseorang pernah pindah atau tidak adalah dengan melihat pada adanya perubahan tempat tinggal seseorang. Perbedaan tempat tinggal inilah yang digunakan sebagai proksi migrasi (BPS, 2012 ; BPS, 2016).

\section{Variabel dan Sumber Data}

Variabel dalam penelitian ini meliputi migrasi risen masuk, migrasi risen keluar, dan migrasi risen neto. Dalam pada itu, migrasi risen neto adalah selisih antara migrasi risen masuk dengan migrasi risen keluar. Migrasi risen neto bernilai negatif jika jumlah migrasi risen masuk lebih kecil dari jumlah migrasi risen keluar, bernilai 0 (nol) jika jumlah migrasi risen masuk sama dengan jumlah migrasi risen keluar, dan bernilai positif jika jumlah migrasi risen masuk lebih besar dari jumlah migrasi risen keluar. Sumber data dalam penelitian ini adalah berasal dari data sekunder yakni data hasil SP 2010 (BPS, 2012) dan data SUPAS 2015 (BPS, 2016). 


\section{Analisis Data}

Data yang digunakan dalam penelitian ini adalah data sekunder. Data tersebut dianalisis menggunakan ukuran tendensi sentral (central tendency) yaitu distribusi frekuensi, nilai rata-rata (mean), median, modus kemudian agar lebih mudah dipahami ditampilkan dalam bentuk tabel (Heumann C. et al, 2018).

\section{HASIL DAN PEMBAHASAN}

\section{Migrasi Risen Masuk}

Berdasarkan data pada tabel 1 total migrasi risen masuk di Provinsi NTB mengalami peningkatan dari 2,57 persen pada tahun 2010 menjadi 3,70 persen pada tahun 2015. Merujuk pada tabel 1 bahwa dari 10 kabupaten/kota di Provinsi NTB terdapat tiga daerah paling mencolok yang menjadi daerah tujuan utama migrasi risen masuk baik pada tahun 2010 maupun 2015, yaitu Kota Mataram, Kota Bima dan Kabupaten Sumbawa Barat. Dengan perkataan lain, tujuan utama migrasi risen masuk di Provinsi NTB tidak hanya wilayah perdesaan (Kabupaten Sumbawa Barat), tetapi juga wilayah perkotaan (Kota Mataram dan Kota Bima). Hasil penelitian ini berbeda dengan Mantra (1992) bahwa tujuan migrasi risen masuk di luar Jawa dan Bali termasuk Provinsi NTB hanya menuju perdesaan.

Tabel 1. Migrasi Risen Masuk Antar Kabupaten/Kota di Provinsi NTB

\begin{tabular}{|c|l|l|l|l|l|}
\hline \multirow{2}{*}{ No. Kabupaten/Kota } & \multirow{3}{*}{ 2010 } & \multicolumn{3}{c|}{ Migrasi Risen Masuk } \\
\cline { 3 - 6 } & & \multicolumn{2}{|c|}{$\mathbf{2 0 1 5}$} \\
\cline { 3 - 6 } & & Jumlah & \%) & Jumlah & \%*) \\
\hline 1 & Kab.Lombok Barat & 12.460 & 2,08 & 13.906 & 2,12 \\
\hline 2 & Kab.Lombok Tengah & 13.543 & 1,57 & 32.776 & 3,59 \\
\hline 3 & Kab.Lombok Timur & 12.227 & 1,11 & 46.739 & 4,02 \\
\hline 4 & Kab.Sumbawa & 11.334 & 2,73 & 7.755 & 1,76 \\
\hline 5 & Kab.Dompu & 3.797 & 1,73 & 5.932 & 2,49 \\
\hline 6 & Kab.Bima & 4.213 & 0,96 & 16.515 & 3,52 \\
\hline 7 & Kab.Sumbawa Barat & 8.337 & 7,25 & 6.183 & 4,64 \\
\hline 8 & Kab.Lombok Utara & 1.570 & 0,78 & 2.756 & 1,30 \\
\hline 9 & Kota Mataram & 36.326 & 9,02 & 33.618 & 7,4 \\
\hline 10 & Kota Bima & 11.645 & 8,37 & 17.016 & 10,65 \\
\hline & Total & 115.652 & 2,57 & 183.196 & 3,79 \\
\hline
\end{tabular}

*) Persentase dihitung berdasarkan jumlah penduduk pada masing-masing kabupaten/kota

Sumber : BPS (2012) (diolah) dan BPS (2016) (diolah)

Meskipun persentase migrasi risen masuk pada tiga daerah yakni Kota Mataram, Kota Bima dan Kabupaten Sumbawa Barat mengalami penurunan pada tahun 2015 dibandingkan 2010, tetapi ketiga daerah tersebut tetap menjadi tujuan utama migrasi risen masuk baik pada tahun 2010 maupun 2015. Ketiga daerah tersebut menjadi tujuan utama migrasi risen masuk berkaitan dengan tingginya nilai Indeks Pembangunan Manusia (IPM) yang dimiliki oleh ketiga daerah tersebut dimana ketiga daerah yakni Kota Mataram, Kota Bima dan Kabupaten Sumbawa Barat baik pada tahun 2010 maupun 2015 memiliki nilai IPM tertinggi dibandingkan 7 kabupaten lainnya di Provinsi NTB. Berdasarkan data BPS (2020) bahwa pada tahun 2010 nilai IPM Kota Mataram sebesar 72,47 (peringkat 1), Kota Bima sebesar 70,11 (peringkat 2), dan Kabupaten Sumbawa Barat sebesar 65,42 (peringkat 3). Disisi lain berdasarkan data BPS (2020) bahwa pada tahun 2015 nilai IPM Kota Mataram sebesar 76,37 (peringkat 1), Kota Bima sebesar 72,99 (peringkat 2), dan Kabupaten Sumbawa Barat sebesar 68,38 (peringkat 3). Hasil penelitian ini sejalan dengan UNDP (2019) bahwa migrasi berasal dari daerah yang memiliki nilai IPM lebih rendah menuju daerah yang memiliki nilai IPM lebih tinggi.

Disisi lain, berdasarkan data pada tabel 1 bahwa dari 10 kabupaten/kota di Provinsi NTB pada 7 kabupaten/kota terjadi peningkatan persentase migrasi risen masuk pada tahun 2015 dibandingkan 2010 dimana kabupaten/kota dimaksud adalah Kabupaten Lombok Barat, Kabupaten Lombok Tengah, Kabupaten Lombok Timur, Kabupaten Lombok Utara, Kabupaten Dompu, Kabupaten Bima, Kota Bima. Sedangkan penurunan persentase migrasi risen masuk terdapat pada 3 kabupaten/kota yaitu Kota Mataram, Kabupaten Sumbawa dan Kabupaten Sumbawa Barat. Hal ini menggambarkan bahwa pola migras risen masuk antara tahun 2010 dan 2015 yakni terjadi peningkatan pada 7 kabupaten/kota dan penurunan pada 3 kabupate/kota. Sebelumnya telah dibahas bahwa terdapat tiga daerah paling mencolok yang menjadi daerah tujuan migrasi yaitu Kota Mataram, Kota Bima dan Kabupaten Sumbawa Barat. Berdasarkan data BPS (2012) dan BPS (2016) bahwa sebagian besar migran yang masuk ke Kota Mataram berasal dari kabupaten terdekat yaitu Lombok Barat, Lombok Tengah dan Lombok Timur kemudian migran yang masuk ke Kota Bima berasal 
dari Kabupaten Bima dan Kabupaten Dompu, sementara migran yang masuk ke Kabupaten Sumbawa Barat berasal dari Kabupaten Sumbawa dan Kabupaten Lombok Timur. Hal ini sejalan dengan Everett Lee dan Thomas Stoufer dalam Mantra (1992) bahwa migran cenderung memilih tempat terdekat sebagai daerah tujuan.

\section{Migrasi Risen Keluar}

Berdasarkan data pada tabel 2 total migrasi risen keluar di Provinsi NTB mengalami peningkatan dari 2,42 persen pada tahun 2010 menjadi 2,57 persen pada tahun 2015. Disisi lain pada tabel 2 tampak tiga kabupaten/kota yang memiliki persentase migrasi risen keluar tertinggi yakni Kabupaten Bima kemudian disusul Kota Mataram dan Kabupaten Sumbawa pada tahun 2010.

Tabel 2. Migrasi Risen Keluar Antar Kabupaten/Kota di Provinsi NTB

\begin{tabular}{|c|c|c|c|c|c|}
\hline \multirow[t]{3}{*}{ No. } & \multirow{3}{*}{ Kabupaten/Kota } & \multicolumn{4}{|c|}{ Migrasi Risen Keluar } \\
\hline & & \multicolumn{2}{|c|}{2010} & \multicolumn{2}{|c|}{2015} \\
\hline & & Jumlah & $\% *)$ & Jumlah & $\% *)$ \\
\hline 1 & Kab.Lombok Barat & 12.482 & 2,08 & 15.328 & 2,34 \\
\hline 2 & Kab.Lombok Tengah & 17.135 & 1,99 & 16.137 & 1,77 \\
\hline 3 & Kab.Lombok Timur & 19.672 & 1,78 & 19.230 & 1,65 \\
\hline 4 & Kab.Sumbawa & 11.574 & 2,78 & 12.304 & 2,79 \\
\hline 5 & Kab.Dompu & 5.230 & 2,39 & 9.504 & 3,99 \\
\hline 6 & Kab.Bima & 21.627 & 4,92 & 20.969 & 4,47 \\
\hline 7 & Kab.Sumbawa Barat & 1.567 & 1,36 & 3.692 & 2,77 \\
\hline 8 & Kab.Lombok Utara & 2.330 & 1,16 & 3.164 & 1,49 \\
\hline 9 & Kota Mataram & 14.889 & 3,70 & 17.206 & 3,82 \\
\hline 10 & Kota Bima & 2.480 & 1,74 & 6.696 & 4,19 \\
\hline & Total & 108.986 & 2,42 & 124.230 & 2,57 \\
\hline
\end{tabular}

*) Persentase dihitung berdasarkan jumlah penduduk pada masing-masing kabupaten/kota

Sumber : BPS (2012) (diolah) dan BPS (2016) (diolah)

Berdasarkan tabel di atas, tiga kabupaten/kota yang memiliki persentase migrasi risen keluar tertinggi pada tahun 2015 yakni Kabupaten Bima, Kota Bima, dan Kabupaten Dompu. Berdasarkan data BPS (2012) dan BPS (2016) bahwa daerah tujuan migrasi risen keluar yakni daerah terdekat dimana Kota Bima menjadi daerah tujuan untuk Kabupaten Bima, Kabupaten Lombok Barat untuk Kota Mataram, Kabupaten Sumbawa Barat untuk Kabupaten Sumbawa. Dalam pada itu, Kota Bima menjadi daerah tujuan untuk migrasi risen keluar dari Kabupaten Bima, Kabupaten Bima untuk Kota Bima dan Kota Bima untuk Kabupaten Dompu.

Hal tersebut diatas menggambarkan bahwa selain migrasi risen masuk, migrasi risen keluar juga sejalan dengan Everett Lee dan Thomas Stoufer dalam Mantra (1992) bahwa migran cenderung memilih tempat terdekat sebagai daerah tujuan. Data pada tabel 2 menunjukkan bahwa pola migrasi risen keluar antara tahun 2010 dan 2015 yakni terjadi peningkatan persentase migrasi risen keluar pada 7 kabupaten/kota yaitu Kota Mataram, Kabupaten Lombok Barat, Kabupaten Lombok Utara, Kabupaten Sumbawa, Kabupaten Sumbawa Barat, Kabupaten Dompu dan Kota Bima dan penurunan pada 3 kabupaten yaitu Kabupaten Lombok Tengah, Kabupaten Lombok Timur dan Kabupaten Bima.

\section{Migrasi Risen Neto}

Berdasarkan data pada tabel 3 total migrasi risen neto di Provinsi NTB mengalami peningkatan dari 0,15 persen pada tahun 2010 menjadi 1,22 persen pada tahun 2015. Migrasi risen neto adalah selisih antara migrasi risen masuk dengan migrasi risen keluar. Migrasi risen neto bernilai negatif jika jumlah migrasi risen masuk lebih kecil dari jumlah migrasi risen keluar, bernilai 0 (nol) jika jumlah migrasi risen masuk sama dengan jumlah migrasi risen keluar, serta bernilai positif jika jumlah migrasi risen masuk lebih besar dari jumlah migrasi risen keluar.

Tabel 3. Migrasi Risen Neto Antar Kabupaten/Kota di Provinsi NTB

\begin{tabular}{|c|l|l|l|l|l|}
\hline \multirow{2}{*}{ No. } & \multirow{2}{*}{ Kabupaten/Kota } & \multicolumn{3}{c|}{ Migrasi Risen Neto } \\
\cline { 3 - 6 } & & \multicolumn{2}{c|}{$\mathbf{2 0 1 0}$} & \multicolumn{2}{c|}{$\mathbf{2 0 1 5}$} \\
\cline { 3 - 5 } & & Jumlah & \%) & \multicolumn{1}{c|}{ Jumlah } & \% $)$ \\
\hline 1 & Kab.Lombok Barat & -22 & 0,00 & -1.422 & $-0,22$ \\
\hline 2 & Kab.Lombok Tengah & -3.592 & $-0,42$ & 16.639 & 1,82 \\
\hline 3 & Kab.Lombok Timur & -7.445 & $-0,67$ & 27.509 & 2,36 \\
\hline 4 & Kab.Sumbawa & -240 & $-0,06$ & -4.549 & $-1,03$ \\
\hline 5 & Kab.Dompu & $-1,433$ & $-0,65$ & -3.572 & $-1,50$ \\
\hline 6 & Kab.Bima & -17.414 & $-3,96$ & -4.549 & $-0,95$ \\
\hline
\end{tabular}




\begin{tabular}{|c|l|l|l|l|l|}
\hline 7 & Kab.Sumbawa Barat & 6.770 & 5,89 & 2.491 & 1,87 \\
\hline 8 & Kab.Lombok Utara & -760 & $-0,38$ & -408 & $-0,19$ \\
\hline 9 & Kota Mataram & 21.437 & 5,32 & 16.412 & 3,65 \\
\hline 10 & Kota Bima & 9.365 & 6,57 & 10.320 & 6,46 \\
\hline & Total & 6.666 & 0,15 & 58.966 & 1,22 \\
\hline
\end{tabular}

*) Persentase dihitung berdasarkan jumlah penduduk pada masing-masing kabupaten/kota

Sumber : BPS (2012) (diolah) dan BPS (2016) (diolah)

Data pada tabel 3 menunjukkan bahwa pola migrasi risen neto pada tahun 2010 berbeda dengan tahun 2015 dimana persentase migrasi risen neto negatif terjadi pada 6 kabupaten yaitu Kabupaten Lombok Tengah, Kabupaten Lombok Timur, Kabupaten Sumbawa, Kabupaten Dompu, Kabupaten Bima, dan Kabupaten Lombok Utara kemudian migrasi risen neto 0 (nol) pada 1 (satu) kabupaten yakni Kabupaten Lombok Barat dan migrasi risen neto positif pada 3 kabupaten/kota yaitu Kabupaten Sumbawa Barat, Kota Mataram, dan Kota Bima. Sedangkan pada tahun 2015 persentase migrasi risen neto negatif terjadi pada 5 kabupaten yaitu Kabupaten Lombok Barat, Kabupaten Sumbawa, Kabupaten Dompu, Kabupaten Bima, dan Kabupaten Lombok Utara selanjutnya migrasi risen neto positif pada 5 kabupaten/kota yakni Kabupaten Lombok Tengah, Kabupaten Lombok Timur, Kabupaten Sumbawa Barat, Kota Mataram, dan Kota Bima.

Dalam teori rantai migrasi yang dikemukakan Massey dalam de Haas (2017) bahwa migran yang telah lama bermukim di daerah tujuan dapat berperan sebagai pemberi informasi mengenai kondisi daerah tujuan kepada non-migran yakni teman, sahabat, kerabat yang dimilikinya di daerah asal, sehingga informasi tersebut akan tersebar secara berantai dan hal inilah yang akan mendorong penduduk daerah asal untuk bermigrasi ke daerah tujuan. Dalam konteks migrasi risen, migran asal Pulau Lombok yang telah lama bermukim sebagai transmigran pada sejumlah kabupaten di Pulau Sumbawa dapat memberikan informasi kepada non-migran ke Pulau Lombok yang akan mendorong penduduk Pulau Lombok untuk bermigrasi ke Pulau Sumbawa. Namun hasil penelitian ini berbeda dengan Massey dalam de Haas (2017) bahwa yang terjadi adalah sebagaimana telah dibahas sebelumnya justru migran cenderung memilih tempat terdekat sebagai tujuan.

Dalam pada itu, data pada tabel 3 juga menunjukkan bahwa dari 10 kabupaten/kota di Provinsi NTB perubahan dari migrasi neto neto negatif pada tahun 2010 menjadi migrasi neto positif pada tahun 2015 hanya ditemukan pada 2 kabupaten yakni Kabupaten Lombok Tengah dan Kabupaten Lombok Timur dengan persentase migrasi neto positif terbesar di Kabupaten Lombok Timur. Hal ini terjadi karena dari 5 kabupaten/kota di Pulau Lombok hanya Kabupaten Lombok Timur yang belum mencapai bonus demografi, sehingga terjadi mobilitas tenaga kerja dari 4 kabupaten/kota yang telah mencapai bonus demografi ke Kabupaten Lombok Timur yang belum mencapai bonus demografi. Menurut Kabul et al (2020) bahwa kabupaten Lombok Timur belum mencapai bonus demografi karena rasio ketergantungan (dependency ratio) yang dimiliki Lombok Timur pada tahun 2015 sebesar 51,41 atau diatas 50 sedangkan 4 kabupaten/kota lainnya di Pulau Lombok telah mencapai bonus demografi karena memiliki rasio ketergantungan dibawah 50 .

\section{SIMPULAN DAN SARAN}

\section{Simpulan}

1. Migrasi risen masuk di Provinsi NTB mengalami peningkatan dari 2,57 persen pada tahun 2010 menjadi 3,70 persen pada tahun 2015. Pada 7 kabupaten/kota terjadi peningkatan persentase migrasi risen masuk pada tahun 2015 dibandingkan 2010 dimana kabupaten/kota dimaksud adalah Kabupaten Lombok Barat, Kabupaten Lombok Tengah, Kabupaten Lombok Timur, Kabupaten Lombok Utara, Kabupaten Dompu, Kabupaten Bima, Kota Bima. Sedangkan penurunan persentase migrasi risen masuk terdapat pada 3 kabupaten/kota yaitu Kota Mataram, Kabupaten Sumbawa dan Kabupaten Sumbawa Barat.

2. Migrasi risen keluar di Provinsi NTB mengalami peningkatan dari 2,42 persen pada tahun 2010 menjadi 2,57 persen pada tahun 2015. Pola migrasi risen keluar antara tahun 2010 dan 2015 yakni terjadi peningkatan persentase migrasi risen keluar pada 7 kabupaten/kota yaitu Kota Mataram, Kabupaten Lombok Barat, Kabupaten Lombok Utara, Kabupaten Sumbawa, Kabupaten Sumbawa Barat, Kabupaten Dompu dan Kota Bima dan penurunan pada 3 kabupaten yaitu Kabupaten Lombok Tengah, Kabupaten Lombok Timur dan Kabupaten Bima.

3. Migrasi risen neto di Provinsi NTB mengalami peningkatan dari 0,15 persen pada tahun 2010 menjadi 1,22 persen pada tahun 2015. Pola migrasi risen neto pada tahun 2010 berbeda dengan tahun 2015 dimana persentase migrasi risen neto negatif terjadi pada 6 kabupaten yaitu Kabupaten Lombok Tengah, Kabupaten Lombok Timur, Kabupaten Sumbawa, Kabupaten Dompu, Kabupaten Bima, dan Kabupaten 
Lombok Utara kemudian migrasi risen neto 0 (nol) pada 1 (satu) kabupaten yakni Kabupaten Lombok Barat dan migrasi risen neto positif pada 3 kabupaten/kota yaitu Kabupaten Sumbawa Barat, Kota Mataram, dan Kota Bima. Sedangkan pada tahun 2015 persentase migrasi risen neto negatif terjadi pada 5 kabupaten yaitu Kabupaten Lombok Barat, Kabupaten Sumbawa, Kabupaten Dompu, Kabupaten Bima, dan Kabupaten Lombok Utara selanjutnya migrasi risen neto positif pada 5 kabupaten/kota yakni Kabupaten Lombok Tengah, Kabupaten Lombok Timur, Kabupaten Sumbawa Barat, Kota Mataram, dan Kota Bima. Pola perubahan dari migrasi neto neto negatif pada tahun 2010 menjadi migrasi neto positif pada tahun 2015 hanya ditemukan pada 2 kabupaten yakni Kabupaten Lombok Tengah dan Kabupaten Lombok Timur dengan persentase migrasi neto positif terbesar di Kabupaten Lombok Timur.

\section{Saran-saran}

1. Penelitian ini menggunakan dua deret waktu, yakni SP 2010 dan SUPAS 2015, untuk itu kedepan penelitian ini hendaknya dapat ditindak-lanjuti dengan penelitian migrasi risen berdasarkan tiga deret waktu yakni SP 2010, SUPAS 2015 dan SP 2020.

2. Dalam penelitian ini tidak dibahas mengenai dampak sosial ekonomi migrasi risen, oleh karena itu kedepan penelitian ini perlu ditindak-lanjuti dengan penelitian yang berkaitan dengan tentang dampak sosial ekonomi migrasi risen.

3. Ruang lingkup penelitian hanya membahas migrasi risen (ricent migration) dan tidak membahas migrasi seumur hidup (life time migration). Dalam konteks migrasi internal antar kabupaten/kota, migrasi seumur hidup yakni jika kabupaten/kota temapu kelahiran seseorang berbeda dari kabupaten/kota tempat tinggalnya sekarang. Migrasi risen dan migrasi seumur hidup, keduanya saling melengkapi. Berkaitan dengan hal tersebut,maka penelitian ini peril ditindak-lanjuti dengan penelitian yang mencakup migrasi risen dan migrasi seumur hidup.

\section{DAFTAR PUSTAKA}

BPS NTB. (2020). Indeks Pembangunan Manusia Provinsi Nusa Tenggara Barat 2010-2019 (Metode Baru). Mataram: Badan Pusat Satistik NTB

BPS. (2019). Analisis Mobilitas Tenaga Kerja Hasil Survei Angkatan Kerja Nasional 2018. Jakarta: Badan Pusat Statistik

BPS. (2012). Statistik Migrasi Nusa Tenggara Barat Hasil Sensus Penduduk 2010. Jakarta: Badan Pusat Statistik

BPS. (2016). Statistik Migrasi Nusa Tenggara Barat Hasil Survei Penduduk Antar Sensus 2015. Jakarta: Badan Pusat Statistik

de Haas Hein. (2017). Migration and Development: A Theoritical Perspective. Center on Migration, Citizenship and Development, Bielefeld, Germany

Haris, Abdul. (2002). Memburu Ringgit Membagi Kemiskinan: Fakta Dibalik Migrasi Orang Sasak ke Malaysia. Yogyakarta: Pustaka Pelajar

Heumann Christian, Micahel Schomaker, Shalabh. (2018). Introduction to Statistics and Data Analysis. Switzerland: Springer International Publihsing

Kabul LM, JN Darenoh, A Subhani. (2020). Pengembangan Model dan Metode Perhitungan Bonus Demografi. GEODIKA: Jurnal Kajian Ilmu dan Pendidikan Geografi 4 (2), 138-147.

Kurnia, Novianti. (2010). Analisis Trend dan Dampak Pengiriman TKI:Kasus Dua Desa di Lombok Timur NTB. Jurnal Kependudukan Indonesia, LIPI, Vol. 5 No.1.

Mantra. Ida Bagoes. (2000). Demografi Umum. Yogyakarta: Pustaka Pelajar

Mantra Ida Bagoes. (1998). Indonesian Labor Mobility to Malaysia ( A Case study:East Lombok, Flores and The Island of Bawean). Paper pada National Workshop on International Migration, 9-11 Maret 1998. The Population Studies Center. Yogyakarta: Universitas Gadjah Mada

Mantra, Ida Bagoes. (1992). Pola dan Arus Migrasi Penduduk Antar Provinsi Di Indonesia Tahun 1990. Populasi 2(3):39-59.

Mantra, Ida Bagoes, 1978.Population Movement in Wet Rice Communities: A Case study in Two Dukuh in Yogyakarta Special Region. Honolulu: University of Hawaii

Neuman Lawrence,W.(2014). Social Research Methods: Qualitative and Quantitative Approaches. Seventh Edition Pearson, England.

Retno Dwi et al. (2008). Bahan Ajar Pemanfaatan Data Satistik Bagi Perencana dan Pengambil Kebijakan. BPS \& UNFPA, Jakarta.

Sudibia IK, Dayuh Rimbawa IN, Adnyana IB. (2012). Pola Migrasi dan Karaketrisktik Migran Berdasarkan Hasil Sensus Penduduk 2010 di Provinsi Bali. Piramida, Vol.VIII 
Sukamdi \& Gazy Mujahid. (2015). Internal Migration in Indonesia. Monograph Series No.3. Jakarta: UNFPA Indonesia,

Sunarto HS. (1993). Permasalahan Penduduk Di Indonesia dan Cara-Cara Pemecahannya. Cakrawala Pendidikan Edisi 3:69-79.

UNDP. (2009). Human Development Report 2009 Overcoming barriers: Human mobility and development. New York: Palgrave Macmillan

Wirasapta Karyadi, L. (2013). Migrasi Internasional Tenaga Kerja Indonesia (TKI) Daerah Asal Pulau Lombok ke Malaysia: Tinjauan Sosiologis. Mataram: Mataram University Press 